\title{
MEMAHAMI RELASI MUTLAQ DAN MUQAYYAD DALAM TAFSIR AL QURAN
}

\author{
Hidayatul Munawaroh \\ Pengajar Al Quran Sekolah Raudlatul Jannah Sidoarjo \\ Hidayatulmunawaroh123@gmail.com
}

\begin{abstract}
Abstrak
Lafaz-lafaz dalam Al Quran ada yang bermakna umum general. Ada yang bermakna khusus spesifik. Kompetensi dasar menentukan mana yang general dan mana yang spesifik sungguh dibutuhkan dalam tafsir Al Quran. Mengingat Al Quran adalah rujukan yuresprudensi Islam, maka kompetensi dasar ini menjadi mutlak. Perbedaan menentukan mutlaq dan muqoyyag kadang pula terjadi yang lalu menimbulkan perbedaan tafsir. Berbagai pola bentuk mutlaq dan muqayyad ada dalam gramatika Al Quran.Tentu saja mutlaq dan muqayyad adalah salah satu aspek saja dalam kaidah atau gramatika kompetensi dasar penafsiran Al Quran. Hanya dengan memahami aspek ini jelas tidak cukup. Namun tanpa memahami kompetensi ini juga berakibat pada misinterpretasi yang fatal.Dalam kajian mutlaq dan muqayyad, ada bentuk-bentuk relasi untuk menarik kesimpulan dari nash-nash yang berbentuk mutlaq dan muqayyad. Pertama, sebab dan hukumnya sama. Kedua, sebab dan hukumnya berbeda. Ketiga, sebab berbeda, tetapi hukum sama. Keempat, sebab sama tapi hukum berbeda.
\end{abstract}

Kata kunci: muqayyad, mutlaq, lafadz, Al Quran

\section{A. Pendahuluan}

Aktivitas mengkaji Al Quran untuk memaknai teks-teks tersurat atau yang eksplisit dan implisit dalam Al Quran akan senantiasa menjadi determinasi atau langkah penentu umat Islam dalam menafsir maknanya. Kebutuhan untuk menangkap makna Al Quran baik dalam kerangka penghayatan amaliah sehari-hari maupun dalam kerangka kajian ilmiah (studi Islam), secara simultan dan terusmenerus dilakukan umat Islam. Interpretasi tentang isi dan makna sumber bacaan memang akan selalu berkecamuk dalam pikiran semua pembaca untuk mendapatkan kebermaknaan dari sumber bacaan.

Sebagai wahyu yang diyakini dan diakui universalitas sekaligus relevansinya untuk segala zaman dan generasi, Al Quran tidak pernah habis makna. Al Quran diimani oleh umat Islam sebagai puncak kesempurnaan bacaan sesuai dengan namanya: Al Kitab. Al Quran bagai berlian dengan facet yang tidak terhingga. Membaca dan memaknai berulang-ulang selalu menghasilkan facet-facet makna 
yang baru. Nama Al Kitab yang berarti bacaan mengisyaratkan bahwa Al Quran meskipun diturunkan pada generasi pertama umat Islam yang ummi, yaitu generasi yang tidak punya tradisi baca-tulis yang kuat, tetapi tetap bisa dibaca untuk generasi-generasi berikutnya yang telah mencapai peradaban baca-tulis lebih maju.

Dengan wawasan seperti yang diuraikan di atas, kontekstualisasi pemahaman pada makna Al Quran menjadi urgen untuk kepentingan meraih petunjuk bagi kehidupan manusia. Quraish Shihab memberikan wawasan.

Al Quran memperkenalkan dirinya sebagai hudan li al nās (petunjuk untuk seluruh umat manusia). Inilah fungsi kehadirannya. Dalam rangka penjelasan tentang fungsi Al Quran ini, Allah menegaskan; Kitab suci diturunkan untuk memberi putusan (jalan keluar) terbaik bagi problem-problem kehidupan manusia (QS, 2: 213). Kita yakin bahwa para sahabat Nabi Muhammad seandainya hidup pada saat ini akan memahami petunjuk Al Quran-sedikit atau banyak- berbeda dengan pemahaman mereka sendiri yang telah tercatat dalam literature keagamaan. Karena pemahaman manusia terhadap sesuatu tidak dapat dilepaskan dari kondisi sosial masyarakat, perkembangan ilmu pengetahuan dan teknologi, pengalaman-pengalaman, di samping kecenderungan dan latar belakang pendidikan. ${ }^{1}$

Penjelasan Quraish Shihab tersebut menggariskan bahwa Al Quran adalah sumber petunjuk yang memberi putusan hukum, terutama bagi umat Islam. Untuk bisa mendapatkan putusan hukum dari Al Quran, maka memahaminya adalah prioritas. Tanpa pemahaman yang jernih dan shahih bagaimana putusan hukum yang bijak dan adil bisa diambil. Mengingat Al Quran yang hadir pada generasi kita sekarang tidak secara langsung disampaikan Rasulullah, tetapi melalui pewarisan teks bacaan, maka memahami ayat-ayat, kalimat per kalimat, bentuk kata-per kata dalam Al Quran yang tertulis itu juga kebutuhan yang mendasar. Salah satu, metode yang dikembang untuk memahami makna ayat-ayat Al Quran adalah mengkajinya dari aspek mutlaq dan muqayyad.

Sebelum menelaah dan mengkaji dua nomenklatur itu, perlu dicatat, bahwa telaah tentang mutlaq dan muqayyad berkaitan dengan pengambilan atau penyimpulan putusan hukum dari ayat-ayat Al Quran, maka tidak bisa dielekkan pembahasan dalam makalah ini akan bersinggungan dengan ushūl fiqih.

Ushūl fiqih, sendiri, sebagaimana dikemukakan Ibnu Khaldun dalam Mukadimahnya, adalah kajian ilmu yang menelaah dalil-dalil syar'i. Ushūl fiqih

\footnotetext{
${ }^{1}$ M. Quraish Shihab, “Memfungsikan Al Quran”, Lentera Hati (Bandung: Mizan, 2001), 31.
} 


\section{Hidayatul Munawaroh}

lalu bisa menjadi metode untuk menetapkan hukum dan taklif. Sumber yang dirujuk dalam dalil-dalil dalam kajian ushūl fiqih adalah Al Quran dan As Sunnah². Pengertian ushūl fiqih sendiri sangat tergantung pada pengertian kata ushūl yang menjadi mudhōf dalam frase itu. Ushūl bisa berarti cabang, dasar, kaidah, permulaan atau yang lebih kuat $^{3}$.

Pada masa Rasulullah segala macam putusan hukum dari berbagai sudut berikut detailnya dapat langsung ditanyakan dan dirujuk pada Rasulullah. Beliau yang mendapatkan wahyu bisa menjadi sandaran tanpa perdebatan dan keraguan. Beliaulah yang langsung menjelaskan kandungan ayat-ayat Al Quran tanpa membutuhkan periwayatan, penelitian, atau Qiyas. Namun pasca masa Rasulullah, tidak dielakkan, kajian untuk mendapatkan putusan-putusan hukum berdasar penafsiran As Sunnah, bersandar pada Ijma' atau melalui Qiyas dilakukan.

Sebagai kajian, ushūl fiqih mendasarkan kajiannya pada sumber Al Quran, As Sunnah, Ijma', Qiyas. Mayoritas ulama sepakat keempat entitas itu adalah sumber dalil-dalil syar'i meskipun harus segara dicatat, sebagian mereka ada yang tidak sepakat dengan penggunaan Ijma' dan Qiyas. Mustofa Zarqo memilah keempat itu menjadi dua kategori, yaitu. Al Quran dan Al Hadith adalah sumber utama atau al masādir al asāsiyyah karena semua ulama sepakat. Ijma' dan Qiyas atau Istihsan, semenatara itu adalah sumber sekunder atau al masādir at taba'iyyah ${ }^{4}$.

Sebagai bagian dari Ulūmu Al Qurāan, mutlaq dan muqayyad penting difahami. Keduanya adalah kajian untuk mempertegas maksud kandungan dari redaksi ayat-ayat atau nash-nash Al Quran. Pertama-tama pemahaman itu sebaiknya diawali berdasarkan makna kamus, mutlaq berarti terlepas, bebas. Demikian Kamus Al Munawwir mengartikan lema ini. ${ }^{5}$ Istilah mutlaq ini kiranya harus dijernihkan dari pengertian mutlaq dalam bahasa Indonesia. Meskipun mutlaq dalam bahasa Indonesia adalah serapan dari bahasa Arab tersebut, tetapi ketika diserap ke dalam bahasa Indonesia telah terjadi pergeseran makna dari makna asalnya. Kosa kata mutlak dalam bahasa Indonesia bisa berarti sepenuhnya. Contoh kalimat: Kita yakin

\footnotetext{
2 Ibnu Khaldun, "Ilmu Ushul Fikih dan Klasifikasi Al Jadal dan Al Khilafiyat", Mukadimah, terj. (Jakarta: Al Kautsar, 2001), 836.

${ }^{3}$ Ensiklopedia Islam, (Jakarta: Penerbit Ichtiar Baru VanHouve, 1992) jidil V, 146

${ }^{4}$ Ibid., jilid II, 9.

${ }^{5}$ A. M. Munawwir, Kamus Al Munawwir Arab-Indonesia, (Surabaya: Pustaka Progresif, 1997), 862.
} 
pada hari kiamat secara mutlak. Agak sulit dimengerti jika mutlak dalam kalimat itu diartikan bebas tak terikat. Muqayyad sementara itu adalah, sebagaimana juga diartikan dalam kamus Al Munawwir berarti yang terikat. Istilah ini sepadan dengan makalah imam Syafi', “Al ilmu shoidun wal kitabatu qoiyyiduhā. Qoiyyid shoidaka bil hibālil wātsiqoh."

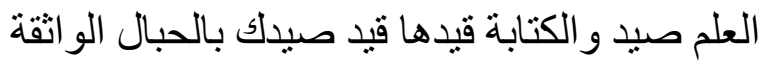

Makalah ini akan membahas tentang pengertian mutlaq dan muqayyad. Pengertian itu akan dilengkapi dengan macam-macam bentuk relasi mutlaq dan muqayyad dan dilengkapi dengan status hukumnya. Sebisanya penulis akan melengkapi dengan contoh-contoh ayat yang berisi mutlaq dan muqayyad.

Dengan pemahaman pada persoalan mutlaq dan muqayyad di atas, pemahaman tentang salah satu metode dalam pemahaman makna dan kandungan Al Quran bisa kita dapatkan meskipun, dalam makalah ini, masih dalam taraf yang umum dan belum sangat mendetail dan rinci.

Dalam rangka memahami kandungan nash-nash Al Quran sebagai rujukan hukum menstimulasi kajian Al Quran dan melakukan penafsiran Al Quran (exegis atau the interpretation of Quran) menjadi penting. Mengkaji isi pesan Al Quran yang valid dan komprehensif membutuhkan perhatian yang kuat akan berbagai berbagai aspek dari Al Quran. Abas Jafer dan Masuma Jafer menjelaskan.

In addition to studying the text itself, scholars have meticulously examined other aspects of this Devine Book, such history of of its compilation, the feature of its composition and the detail of its verses. Over time, this study has evolved into sparate branch of Quranic studies- known as the Quranic science, or ulumul Quran which is distinct from the exagis, or tafsir of Quran ${ }^{6}$.

Uraian dua Jafer di atas menggariskan bahwa studi Al Quran menggarsikan perlunya perhatian yang kuat pada beebagai aspek keilmuan seperti sejarah penyusunan, kandungan-kandungan dalam susunan dan detail-detail ayat-ayat Al Quran. Apalagi pemahaman itu dalam kerangka untuk menggariskan putusan hukum. Maka pemahaman akan mutlaq dan muqayyad sebagai salah ilmu yang melihat detail-detail ayat Al Quran juga sangat bermanfaat untuk menangkap isi pesan yang terkandung.

\footnotetext{
${ }^{6}$ Abas Jafer and Masuma Jafer, Quranic Science, (London: Icas, 2009), 1.
} 


\section{B. Pengertian Mutlaq-Muqayyad}

Sebagaimana dimaklumi, nash-nash Al Quran sebagai rujukan hukum acapkali turun dalam bentuk mutlaq. Yaitu entitas penunjuk pada nomenklatur baik individu, benda yang umum, tidak terbatas dan tidak diberi kriteria sifat atau syarat. Selain berupa mutlaq, pensyariatan itu dibatasi oleh kisi-kisi sifat dan kriteria tertentu. Namun hakikatnya nomenklatur individu itu masih meliputi segala jenis. Pembatasan seperti itu diistilahkan dengan muqyyad. Dalam konteks ulumul Quran, Mannā Khalil al Qattān menjelaskan telah definisi atau istilah terminologi mutlaq dan muqayyad.

Menurut Qattān, mutlaq adalah bacaan yang menunjukkan suatu hakikat tanpa suatu qayid atau (pembatas) ${ }^{7}$. Jadi mutlaq hanya mengacu pada indivdu atau nomenlatur yang tak tertentu. Hakikatnya, hal ikhwal individu itu masih belum terpermanai. Dalam bahasa Inggris disebut dengan absolute ${ }^{8}$. Pemaknaan absolute dalam kamus ini lebih tepat dalam lema absolution, yang berarti pelepasan atau pembebasan. Mutlaq sebagai lafaz biasanya, berbentuk nakiroh atau ism tanpa alif dan lām. Misalnya lafalz roqobah dalam fatahrïu roqobatin.

$$
\text { فتحرير رقبة }
$$

Artinya, maka wajib membebaskan budak (Al Mujadalah, 58: 3). Pernyataan ini meliputi pembebasan seorang budak tanpa terbatas mukmin atau kafir. Lafaz roqobah adalah nakiroh dalam kalimat positif. Namun demikian ada juga yang berbentuk mudhōf wa mudhō ilaih. Aidiyakum ايديكم adalah contohnya.

Muqayyad, sementara itu, adalah lafaz yang menunjukkan sutau nomenkaltur dengan batasan (qoyyid). Seperi roqobah yang dibatasi dengan mukminah: fatahrïru roqobatin mu'minatin.

$$
\text { فتحرير رقبة مؤمنة }
$$

Artinya, maka hendaklah membebaskan budak yang beriman (An Nisa, 4: 92). Muhammad Alwi Maliki Al Husni, dalam bukunya, Zubdatul Itqōn fil Ulümil Qurāan, menerangkan mutlaq adalah penunjuk tanpa batasan. Al Husni merujuk

\footnotetext{
${ }^{7}$ Mannā Khalil al Qattān, Studi Ilmu-Ilmu Al Quran, terj., (Bogor: Litera Antar Nusa, 2013), 350.

${ }^{8}$ Hasan Sadli dan John Ecols, Kamus Inggris-Indonesia, (Jakarta: Gramedia 2000), 4.
} 
pada pendapat banyak ulama bahwa ketika ditemukan dalil dengan pembatasan, maka yang mutlaq disandarkan pada pembatas itu, tetapi jika tidak ditemukan maka tidak berlaku pembatasan tersebut. Maka posisi mutlaq dibiarkan dalam kebebasannya. Muqayyad, sementara itu apa yang dibatasi atau disandarkan pada sesuatu. Semisal, kata aidiy dalam perintah wudlu mendapat qoyyid ilal maröfiqi. Begini definisi yang diuraikan oleh Al Husni dalam kitabnya tersebut: الدال على Segala yang umum tanpa pembatas. ${ }^{9}$

Dengan demikian pengertian muqayyad adalah segala sesuatu yang memiliki pembatas. Contoh pada surat Albaqoroh dalam dialog Nabi Musa dengan Bani Israil tentang perintah penyembelihan sapi.

Mereka diminta untuk menyembelih sapi tanpa kualifikasi, tanpa spesifikasi tanpa atribut dan tanpa pembatas, awalnya. Namun kemudian mereka menanyakan spesifikasi sapi itu. Lalu, dijelaskanlah spesifikasi sapi itu انها بقرة لا فارض و لا بكر.

Kasus lain yang menujukkan pentingnya memahami mutlaq dan muqayyad bila dirujuk dari kalimat yang diutarakan Az Zuhri. Ahli Hadith yang diminta Umar ibnu Abd Aziz mengkodifikasi hadith-hadith Nabi. Kalimat atau makalahnya yang lengkap mengomentari perintah kebijakan penguasa tentang kodifikasi Hadith begini,

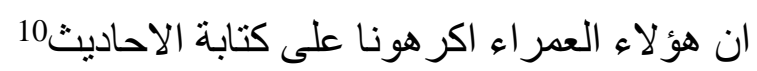

Artinya, Sesungguhnya mereka para penguasa itu memaksa kami menulis hadith-hadith. Namun kalimat ini oleh seorang orientalis Iqnas Gholdziher diubah dari احاديث menjadi. Yang pertama jelas merujuk pada hadith-hadith Nabi. Sedangkan yang kedua bisa jadi sembarang hadith atau yang dianggap hadith. Perbadaan isim makrifat dan nakiroh dalam kontek kalimat ungkapan Az Zuhri bisa berdampak fatal. Dengan menggunakan makrifat berarti bentuk muqayyad, maka kita akan berasumsi kuat bahwa hanya hadith-hadith yang shohih yang benatr-benar berasal dari Nabi yang dikodifikasi tim Az Zuhri. Sedangkan, nakiroh bisa berarti

\footnotetext{
${ }_{9}^{9}$ Muhammad Ali bin Khusni Al Maliki, Hāsyiah Al Athōr 'Alā jam'i Al Jawāmi', (Beirut: Darul Kutub Al 'Alamiyaah, Tanpa Tahun), Jilid II, 79

${ }^{10}$ Ali Mustofa Yaqub, Kritik Hadith, (Jakarta: Firdaus, 1996), 10
} 
mutlaq, berarti sembarang hadith baik yang jelas kesahihannya maupun yang tidak jelas ke-shahihan-nya.

Pengertian tentang mutlaq dan muqayyad yang diuraikan, ada baiknya dilengkapi dengan wawasan ulama atau sarjana modern yang mengartikulasikan keilmuannya dalam bahasa Inggris. Shaykh Yaser Birjas, lulusan Universitas Madinah, pengajar di Institute Al Maghrib tetapi tinggal dari Amerika menjelaskan dalam berbagai kuliahnya.

Al-Mutlaq, the absolute (No retriction). It is a word that is not limited, nor qualified in its aplication. It includes everythng with no retrictions. So what do you do when you find such a ruling in the Qoran or Hadith. The absolute understanding of Ayah or Hadith (Mutlaq) is applied, unless you bring eveidence that suggest any retriction or qualification. Ruling mutlaq, the absolute ruling that it alludes to is applied as there is no qualification or retriction (Muqayyad) ${ }^{11}$.

Mutlaq merupakan entitas tanpa batasan. Mutlaq adalah kata yang tidak terbatas atau tidak dikualifikasi dalam penerapan hukumnya. Mutlaq menyangkut segala sesuatu yang tida terbatas. Dengan pengertian ini, apa yang bisa dilakukan ketika ditemukan aturan semacam itu dalam Al Qura dan hadith? Mutlaq diterapkan sejauh tidak ditemukan bukti yang menguatkan bahwa pembatas atau kualifikasi terhadap yang mutlaq tersebut.

Tentang muqayyad, sementara itu, Birjas juga menjelaskan, "Basically, the muqayyad is an adjective of mutlaq. When mutlaq become restricted or qualified by another word or words it becomes muqayyad ${ }^{12}$." Masih menurut Birjas bahwa pada dasarnya muqayyad adalah kata sifat atau atribut pada mutlaq. Ketika mutlaq dibatasi atau diberi kualifikasi dengan kata atau frase, maka mutlaq menjadi muqoyaad.

\section{Bentuk-Bentuk Relasi Mutlaq dan Muqayyad}

Sejumlah bentuk relasi mutlaq dan muqayyad dalam hukum oleh Qattān dijelaskan dalam empat kategori bentuk. Sementara oleh Rachmat Syafe'i

\footnotetext{
${ }^{11}$ Shaykh Yaser Birjas, Principle and Methodology os Islamic Law Part 2, www. Almaghrib.org/instructors/yaser-birjas. 12 Ibid.
} 
dijelaskan dalam lima bentuk. Lima bentuk relasi mutlaq dan muqayyad menurut Rachmta Syafe'i adalah sebagai berikut. ${ }^{13}$ Pertama, suatu lafaz diungkapkan dengan bentuk mutlaq dalam suatu nash, tetapi di nash lain berbentuk muqayyad. Kondisi itlaq dan taqyid-nya bergantung pada sebab hukum. Bentuk ini terjadi, misalnya, dalam kasus adanya saksi dalam berwasiat, yaitu adil. Adil menjadi syarat dalam saksi wasiat و واشهدو اذوي عدل منكم. Tetapi dalam kasus jual beli saksi tersebut di-mutlaq-kan. وواشهدوا اذا تبايعتم. Sebab hukum wasiat dan jual beli berbeda dalam dua nash ini ${ }^{14}$.

Bentuk pertama yang dijelaskan oleh Racamat Syafe't tersebut tidak disebutkan dalam uraian Qottān. Bentuk pertama di atas dalam uraian Qottan bisa jadi sama dengan kategori kelima dalam pengerian Qottān yaitu sebab berbeda tetapi hukumnnya sama. Sebagaimana contoh di atas kasus jual beli dan wasiat tentu berebda, tetapi keduanya memerintahkan hukum yang sama yaitu adanya saksi. Jika dalam perkara wasita saksi harus (di-muqayyad-kan) dengan syarat adil, dalam jual beli saksi itu di-mutlaq-kan. Ini sama dengan kafarah dzihar dan pembunuhan tidak terencana. Dalam kasus pembunuhan tidak terencana, kafarahnya harus (dimuqayyad-kan) dengan sahaya beriman. Sedangkan dalam kasus dzihar, kafarhnya di-mutlaq-kan.

$\underline{\text { Kedua }}$, lafah mutlaq dan muqayyad berlaku sama pada hukum dan sebabnya. Bentuk ini seperti dalam kafarah atau penebus dosa untuk sumpah yang tidak terlaksana. Lafaz ini dalam qiroah mutawatir yang terdapat dalam mushaf Ustmani diungkapkan secara mutlaq.

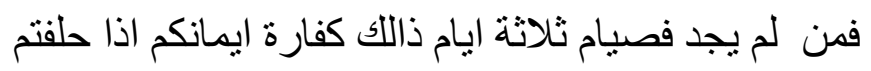

Artinya, barangsiapa tidak sanggup melakukan yang demikian itu, maka kafarahnya adalah puasa tiga hari jika kamu bersumpah (Maidah, 5:89). Dalam mushaf Ibnu Mas'ud lafaz يابام dibatasi dengan متتابعات Dalam hal seperti ini lafaz mutlaq dibawa ke muqayyad. Pengertian lafal mutlaq dan muqayyad sama sebab yang satu tidak akan menjadikan pertentangan yang lain.

\footnotetext{
${ }^{13}$ Racmat Syafe'i. Ilmu Ushul Fiqih (Bandung: Pustaka Setia, 2010), cetakan kesepuluh, 212. ${ }^{14}$ Muhammad Alwi Almaliki Al Husni, Zubdatul itqān fỉ ulūmil qurāan, (Jedah: Darus Syuruq, 1986), 109.
} 


\section{Hidayatul Munawaroh}

Contoh lain yang bisa mempertegas bentuk relasi baik sebab maupun hukum sama sebagaimana diuraikan di poin kedua iani adalah pengharaman terhadap darah.

حرمت عليكم الميتة والدم ولحم الحنزير وما اهل لغير الله به

Diharamkan atas kalian bangkai, darah, daging babi dan apa yang disembelih bukan untuk Allah (Al Maidah: 3). Ayat tentang halal haram konsumsi ini juga ditegaskan ulang di surat Al An'Am: 145):

قل لا اجد فيما احى الى محرما على طاعم يطعمه الا ان يكون ميتة او دما مسفوحا او لحم حنزير

Artinya, saya tidak menemukan di dalam apa yang saya dapatkan dari wahyu tentang makanan diharamkan untuk dimakan kecuali bangkai, darah yang mengalir, daging babi. Jika yang dimaksud, dalam ayat di atas adalah darah. Maka darah yang mengucur adalah haram. Dengan demikian darah yang berasal dari pembuluh vein yaitu sisa-sisa yang masih menempel di daging hewan sembelihan menjadi tidak haram

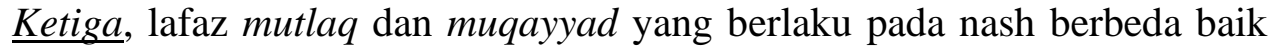
dalam hukumnya maupun sebab hukumnya. Bentuk ini bisa didapat dalam kasus tangan di nash hukuman bagi pencuri dan nash dalam berwudlu. Dalam bermudlu.

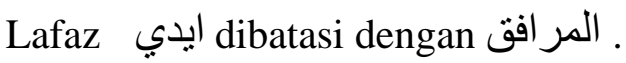

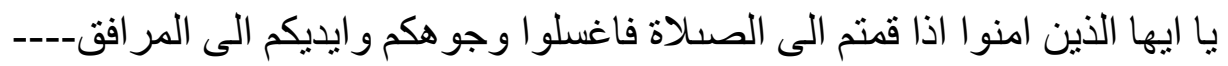

Artinya, wahai orang-orang yang beriman, jika kalian menunaikan sholat basuhlah wajah kalian dan tangan kalian sampai ke siku (Al Maidah: 6). Sementara فاقطعو ايديهما dalam kasus hukuman mencuri berbentuk mutlaq

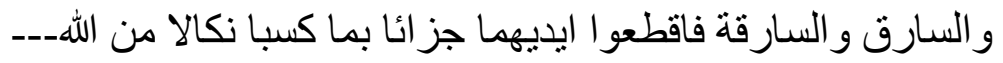

Artinya, dan pencuri lelaki dan pencuri perempuan, maka potonglah tangan keduanya sebagai balasan atas perbutan kedunaya sebagai pelajaran dari Allah (Al Maidah: 38). Dalam kondisi ini mutlaq tidak boleh dibawa kepada muqayyad karena baik sebab maupun hukumnya berbeda.

Keempat, mutlaq dan muqayyad berbeda dalam hukumnya, sedang sebabnya sama. Kasus atau bentuk ini terjadi dalam tangan dalam hal wudlu dan tayamum. Dalam wudlu redaksi nash adalah. 
فاغسلو ا وجو هكم و ايدكم الى المر افق ---

Artinya Basuhlah wajahmu dan tanganmu sampai siku (Al Maidah, 5:6). Sementara dalam nash untuk tayamum tidak dibatasi atau diberi qoyyid (restrictor).

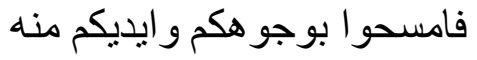

Artinya sapulah mukamu dan tanganmu dengan tanah itu (Al maidah, 5: 6). Karena sebabnya sama sebagian ulama terutama dari kalangan Syafi' yang membawa mutlaq ke muqayyad, tetapi sebagian yang lain tidak. Mutlaq tetap mutlaq dan yang muqayyad tetap muqayyad sehingga hukumnya menjadi berbeda.

Kelima, mutlaq dan muqayyad sama hukumnya, tetapi berbeda dalam sebabnya. Bentuk ini terdaat dalam kasus kasus kafarah pembunuhan dan kafarah dzihar. Mutlaq dalam kasus dzihar dibawa pada muqyaad pada kasus kafarah pembunuhan tidak sengaja. Sebabnya berebeda tetapi hukumnya sama. Dalam kafarah pembunuhan ada nash.

$$
\text { ومن قتل مؤمنا خطا فتحرر رقبة مؤمنة }
$$

Artinya, Barangsiapa membunuh seorang mukmin tanpa terencana, maka baginya membebaskan budak sahaya yang beriman (Annisa, 4:93). Dalam kasus kafarah dzihar sementara itu, tidak ada muqayyadnya.

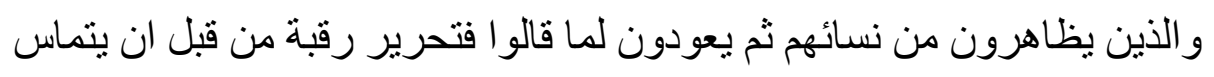

Artinya, dan mereka yang menzihar isteri mereka, kemudian mereka ingin menarik apa yang mereka ucapkan, maka wajib atas mereka membebaskan hamba sahaya (Al Mujadilah, 58:3).

\section{Status Hukum Mutlaq-Muqayyad}

Berdasarkan lima bentuk relasi menurut Rachmat Syafe'i dan empat bentuk relasi menurut Qottān, bentuk mutlaq dan muqayyad yang teruraiakan di atas, di kalangan ulama ada yang bersepakat ada yang tidak bersepakat. 1) Jika hukum dan sebabnya sama, seperti dalam kasus kafarah puasa bagi seorang muslim yang mengingkari sumpahnya, atau dalam pengharaman darah, maka para ulama sepakat membawa lafazh mutlaq dibawa ke muqayyad. 2) Jika hukum dan sebabnya berbeda, seperti dalam kasus tangan dalam batasan berwudlu dan batasan tangan yang dipotong dalam kasus pencurian, maka para ulama sepakat untuk tidak membawa mutlaq ke muqayyad. Ijmak ulama memberlakukan mutlaq pada ke- 


\section{Hidayatul Munawaroh}

mutlaq-annya dan muqayyad pada ke-muqoyaad-annya. 3) Sebagaimana, pada hukumnya berbeda tetapi sebabnya sama, seperti dalam kasus batasan tangan yang dibasuh wudlu dengan batasan tangan yang diusap untuk tayamum, maka para ulama sepakat pula bahwa tidak boleh membawa lafaz mutlaq ke muqayyad. Masing-masing tetap pada ke-mutlaq-annya dan ke-muqoyaad-annya.

Namun dalam kasus hukumnya sama, tetapi sebabnya berbeda, seperti dalam kafarah dzihar dan pembunuhan tidak terenacana, masalah ini juga diperselisihkan antara sebagian besar ulama dan Ulama hanafiah. Menurut ulama Hanafiah tidak boleh membawa mutlaq pada muqayyad. Masing-masing berdiri sendiri. Konsekuensi hukumnya pada kasus zihar, tidak mensyaratkan pembebasan hamba sahaya mukmin. Sebaliknya pada jumhur ulama, disepakati wajib hukumnya membawa mutlaq pada muqayyad. Dalam kasus ini ulama Syafiiayah memberi catatan, mutlaq dibawa ke muqayyad apabila ada illah (alasan) atau hukum yang sama. Caranya yaitu ditempuh dengan jalan qiyas.

Sebab terjadinya perselisihan atau cara memandang ayat-ayat yang berbeda sehingga menghasilkan hukum yang berbeda. Bagi kalangan Hanafiah, ayat demi ayat dan nash-nash itu berdiri sendiri dan masing-masing bisa menjadi hujjah. Maka pembatasan yang mutlak tanpa dalil itu sendiri justru mempersempit yang tidak diperintah. Sedangkan jumhur berpendapat bahwa ayat-demi ayat dalam satu Al Quran adalah satu kesatuan yang saling berkaitan. Maka apabila ada satu kata yang menjelaskan berarti hukum itu sama di setiap tempat kata itu berada. 


\section{E. Keseimpulan}

Berdasarkan uraian di atas bisa ditegaskan dalam kesimpulan ini bahwa mutlaq adalah lafaz, individu atau nomenklatur yang tidak spesifik, belum berkualifikasi, bebas tidak terikat. Muqayyad, sementara itu, adalah lafaz, individu, nomenklatur yang spesifik, memiliki kualifikasi, terikat dan dibatasi.

Dalam kajian mutlaq dan muqayyad, ada bentuk-bentuk relasi untuk menarik kesimpulan dari nash-nash yang berbentuk mutlaq dan muqayyad. Pertama, sebab dan hukumnya sama. Kedua, sebab dan hukumnya berbeda. Ketiga, sebab berbeda, tetapi hukum sama. Keempat, sebab sama tetapi hukum berbeda.

Kajian mutlaq dan muqayyad sebagai kaidah untuk menentukan hukum dalam Al Quran memang sangat tergantung dari paradigma penafsiran yang dianut ulama. Bagi ulama yang berpandangan ayat atau nash per nash itu berdiri sendiri akan menghasilkan putusan yang berbeda dengan yang berpandangan bahwa ayat atau nash demi nash itu satu bagian dalam Al Quran. Perbedaan semacam itu menjadi khasanah pemikiran studi Islam dan itulah realitas hasil ijtihad ulama sejauh masing-masing memiliki argumen yang kuat dan bisa diterima akal.

Perbedaan pemaknaan dan hasil pemahaman terhadap nash berdasarkan relasi mutlaq dan muqayyad tidak dengan sendirinya menciptakan kerancuan dalam isi atau koten kesucian dan keagungan Al Quran. Harus di bedakan Al Quran sebagai wahyu yang suci dan kesalahan di satu sisi dengan hasil ijtihad manusia dengan pendekatan mutlaq dan muqyyad produk manusia. Disinilah letak kebesaran dan keagungan Al Quran yang terus-menerus membutuhkan kajian dan dialektika untuk menangkap kebenaran wahyu. Sementara kebenaran penafsiran manusia selalu merupakan kebenaran ilmiah yang relatif. Benar secara ilmiah adalah benar yang relatif karena terus-menerus harus diuji. Salah secara ilmiah, juga merupakan kesalahan relatif yang tetap memiliki kemungkinan benar. Demikian juga putusan hukum berdasar pada kaidah mutlaq dan muqooyad. Jika benar adalah kebenaran ijtihadi. Jika salah juga merupakan keslahan istihadi.

Dengan memahami mutlaq dan muqayyad paling tidak, kita yang belajar ilmu-ilmu Al quran akan terdorong untuk memahami ayat sebagi nash Al Quran dari sisi redaksi tekstualnya. Pengayaan pemahaman ini penting untuk meluaskan 
cakrawala paham kajian Islam yang selalu terbuka untuk ditafsir ulang tentu dengan validasi dan tashih yang ketat dan tidak serampangan.

\section{Daftar Pustaka}

Shihab, M Quraish.. Lentera Hati. Bandung: Mizan, 2001

Khaldun, Ibnu. Mukaddimah. Jakarta: Al Kautsar, 2001.

Munawwir, A. M. Kamus Al Munawwir Arab-Indonesia. Surabaya; Pustaka Progresif, 1997.

Ensiklopedia Islam. Jakarta: Ichtiar Baru Van Houve, 1992.

Sadli, Hasan dan Ecols, John. Kamus Bahasa Inggris-Indonesia. Jakarta: Gramedia, 1996.

Qattāan, Mannā al Khalil. Studi Ilmu-Ilmu Al Quran. Bogor: Litera Antar Nusa, 2013

Syafe'i, Rachmat. Ilmu Ushul Fiqih. Bandung: Penerbit Setia, 2010.

Al Husni, Muhammad Alwi Al Maliki. Zubdatu Al Itqōn fi Ulümil Qurān. Jedah: Darusurūq,1987.

Yaqub, Ali Mustofa. Kritik Hadis. Jakarta: Pustaka Firdaus, 1996.

Jaffer, Abbas dan Jaffer, Masuma. Quranic Science. London: Icas, 2009.

Birjas, Shaykh Yaser. Principles and Methodology of Islamic Law Part 2. www. almaghrib.org/ instructors/yaser-birjas. 